\title{
BRANCH MORPHOLOGY IMPACTS COMPARTMENTALIZATION OF PRUNING WOUNDS
}

\author{
by Nathan J. Eisner ${ }^{1}$, Edward F. Gilman ${ }^{2}$, and Jason C. Grabosky ${ }^{3}$
}

\begin{abstract}
Branch diameter relative to the trunk diameter (aspect ratio) impacted the amount of discolored wood that developed in the trunk after branch removal in seedling-propagated red maple (Acer rubrum L.) and live oak (Quercus virginiana L.). More discoloration resulted from removing codominant stems than removing branches that were small compared to trunk diameter. Limbs with aspect ratios greater than 0.39 and 0.59 , for live oak and red maple, respectively, resulted in severe trunk discoloration after removal. The presence of branch collars was an indicator of strong compartmentalization potential in both species. Branches having pith that was continuous with trunk pith developed more extensive discoloration after removal than those without pith connections for both red maple and live oak. Pith connections could be predicted in both species based on the presence of branch collars and angle of branch attachment. There was more variability in discoloration among individual live oak trees than among red maples. Cambium dieback, which is often associated with removing codominant stems, was not affected by any of the branch characteristics measured including aspect ratio.
\end{abstract}

Key Words. Aspect ratio; branch angle; branch protection zone; codominant stems; compartmentalization; discolored wood; pruning; wound; Acer rubrum; Quercus virginiana.

Branches constitute a point of weakness to the health of trees, as the primary points of infection for trunk decay (Toole 1961; Shigo 1975). The importance of the branch protection zone (BPZ) in limiting trunk infection after branch injury or removal has been demonstrated (Aufsess 1975, 1984; Shigo 1985). BPZs are generally recognized as cone-shaped areas of discolored wood at the base of dead branches. The xylem within these BPZs is occluded with decay-resistant compounds (Aufsess 1975; Green et al. 1981). In sycamore (Platanus occidentalis) and several species of maple trees, this zone is marked by a green-colored boundary, approximately 0.5 to $2 \mathrm{~mm}$ wide, which is visible in medial longitudinal sections of the branch union. This reaction zone separates the decayed and discolored wood in the branch stub from healthy sapwood in the trunk (Green et al. 1981; Pearce and Woodward 1986; Pearce 2000).
Reaction zones, in general, resist digestion by most fungi, but the antifungal compounds may be depleted eventually, which results in a breach of the reaction zone. When this occurs, new reaction zones are formed, interior to the preceding one, by the same processes that formed the initial reaction zone (Shigo and Marx 1977; Pearce and Woodward 1986; Pearce 1991, 1996). The result is a succession of reaction zones formed and broken down that leads to the gradual decay of those woody tissues present at the time of wounding. Reaction zones that inhibit the axial spread of pathogens within the stem are considered to be the weakest of those described by the Compartmentalization of Decay in Trees (CODIT) model (Shigo and Marx 1977; Shigo 1986). These types of reaction zones are referred to as "wall one" in the CODIT model.

A CODIT wall one constitutes a temporary barrier to pathogen movement when it occurs at an internodal position in the stem, but it is a long-term barrier when it occurs at the BPZ, resisting the axial spread of decay into the trunk through the branch union. In a BPZ, the CODIT wall one is reinforced by the unique xylem anatomy present at the junction of branch and trunk tissues.

Branch union anatomy has been studied extensively for its role in movement of water within trees (Zimmermann 1978, 1983; Ewers and Zimmermann 1984). A zone of constricted xylem vessels occurs at the base of each branch. This vessel anatomy reduces the flow of water into the branch. The spatial position of this constricted tissue corresponds to the location of BPZ formation.

Unlike branches, the junctions of codominant stems do not possess branch protection zones and are prone to decay when one of the two stems is removed or damaged (Shigo 1985, 1986). The xylem anatomy that is critical to the formation of BPZs at the base of branches is conspicuously absent at the union of codominant stems. Water conductance measurements of codominant stems show little restriction of water flow in these stem junctions (Tyree and Ewers 1991).

Although we are familiar with the internal structure of branch union xylem that makes BPZ formation pos- 
sible, it is not known if its presence can be predicted from the outward appearance of the branch union. For instance, does branch diameter relative to the trunk diameter (aspect ratio) indicate a branch union's susceptibility to decay after the branch is removed? If so, arborists can estimate the aspect ratio in order to predict the likelihood of extensive decay developing into the trunk after branch removal. Toole (1961) noted that little decay was associated with small, subordinate branches compared to larger branches in several southern U.S. hardwood tree species. However, little information is available to quantify the impact of aspect ratio on the amount of decay that results from branch removal, injury, or death. For example, we don't know which anatomical features are indicative of strong compartmentalization at the branch union. Research indicates that the presence of branch collars is a good indicator of BPZ-forming potential (Shigo 1985). However, in some tree species, branch collars are not readily apparent even on small branches.

The objectives of this study were to determine: 1) the maximum aspect ratio associated with strong BPZforming potential, and 2) if the amount of discolored wood that formed after branch removal was related to branch union morphological characteristics such as aspect ratio, angle of branch attachment, and the presence of observable branch collars.

\section{MATERIALS AND METHODS}

Ten field-grown seedling-propagated red maple (Acer rubrum L.) and ten live oak (Quercus virginiana L.) trees of similar provenance were selected for study in USDA Hardiness Zone 8b in Gainesville, Florida, U.S. The red maples were approximately 8 to 10 years old, 10 to 15 $\mathrm{cm}$ (4 to 6 in.) diameter at $15 \mathrm{~cm}$ (6 in.) above the ground, and 4 to $7 \mathrm{~m}$ (13 to $23 \mathrm{ft}$ ) tall. The live oaks were approximately 12 to 14 years old, 18 to $30 \mathrm{~cm}$ (7 to $12 \mathrm{in}$.) diameter at $30 \mathrm{~cm}$ (12 in.) above the ground, and 8 to $10 \mathrm{~m}$ $(26$ to $33 \mathrm{ft}$ ) tall. The trees were growing on a welldrained Millhopper Sand (loamy, siliceous, hyperthermic Grossarenic Paleudults) soil. Red maple trees were irrigated periodically during the study period.

On each of these 20 trees, branch unions were selected based on branch diameter and aspect ratio. Two branches on each tree were chosen for inclusion into each of six aspect ratio categories for a total of 12 branches per tree (Table 1). Trunk and branch diameter were measured for each branch union at $15 \mathrm{~mm}$ (0.6 in.) above the branch bark ridge, and aspect ratio was calcu- lated. Only branches 10 to $25 \mathrm{~mm}$ (0.4 to $1.0 \mathrm{in}$.) in diameter were selected for study. The presence or absence of a branch collar was also recorded at this time. A branch collar was defined as a distinct swelling on the branch base where branch wood joined with trunk wood.

Table 1. Aspect ratio categories were used to select red maple and live oak branch unions.

\begin{tabular}{cc}
\hline Aspect ratio category & Aspect ratios* \\
\hline A & $0.25-0.35$ \\
B & $0.38-0.48$ \\
C & $0.51-0.61$ \\
D & $0.64-0.74$ \\
E & $0.77-0.87$ \\
F & $0.90-1.00$ \\
\hline
\end{tabular}

*Aspect ratio $=$ branch diameter $\div$ trunk diameter. For each species of tree there were 10 trees $\times 6$ ratio categories $\times 2$ branches per category $=$ 120 branches.

In September 1999, all 12 branches were removed from each tree. The pruning cuts extended from just outside of the branch bark ridge on the upper side of the branch, to the outside of the branch collar on the branch's lower side. In cases where branch collars were not readily apparent, the cut was made from just outside the branch bark ridge perpendicularly through the branch.

The branch unions from all ten trees (12 unions per tree $\times 10$ trees $=120$ branch unions) of each species were harvested in January 2000. The harvested samples included the branch union with approximately $2.5 \mathrm{~cm}$ (1.0 in.) and $5.0 \mathrm{~cm}$ (2.0 in.) of intact trunk above and below the branch, respectively. All samples were then split with a sharpened metal wedge along the medial longitudinal plane (i.e., through the pith) and shaved with a razor blade to expose the branch and trunk piths.

The amount of discolored wood that formed after branch removal was used as an indicator of decay susceptibility. Because discolored wood is dead wood, it is likely to decay with time (Shigo 1986) and was therefore used as a predictor of decay potential. The trunk tissue discoloration that resulted from pruning was quantified in several ways. Only discoloration that occurred interior to a reference line, referred to as the cambial dieback line, was measured. The cambial dieback line was drawn on the medial longitudinal surface by connecting the points on the upper and lower sides of the branch where the column of discoloration began to taper into the branch core (Figure 1). These connecting points corresponded to the margin of cambial dieback from the 


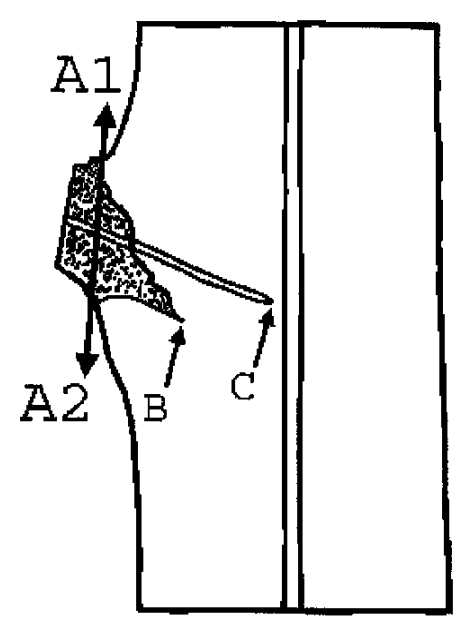

Figure 1. A diagram of a branch junction sample split along the medial longitudinal plane four months after branch removal. The visible area of discolored wood interior to the cambial dieback line (A1 to A2) was measured and correlated with branch aspect ratio. A large intrusion of discoloration (B) and discontinuous branch pith (C) are also shown.

pruning cut on the upper and lower sides of the branch. The length of deepest penetration of discolored wood into the trunk was measured along the grain of the wood on the medial longitudinal surface. The total area of discolored trunk tissue on this surface was measured optically using a light area meter $(\Delta \mathrm{T}$ Area Meter model RS 232C, $\Delta \mathrm{T}$ Devices, Inc. Cambridge, England), which contrasted the dark, discolored wood from the surrounding light-colored wood.

At the time of dissection, the presence or absence and length of included bark visible on the medial longitudinal surface was recorded. The length of the cambial dieback line was also measured to test for relationships between branch angle and cambial dieback. Lastly, samples were evaluated for the presence or absence of pith connection. Pith was connected if branch and trunk pith were continuous.

To account for variability in discoloration measurements due to size differences among samples, all values were normalized before statistical analysis was performed. The length of discolored wood penetration into the trunk was normalized by dividing it by the trunk diameter for each sample. Discolored area was normalized by dividing it by the trunk cross-sectional area. The normalized discolored area values were then $\log$ transformed (base ten) to account for increased variability in discoloration at higher aspect ratios. Included bark length was also normalized by dividing it by the trunk diameter.

The general linear models (GLM, SAS Institute, Inc., version 8.0) procedure was used to test the impact of all continuous variables (aspect ratio, branch diameter, branch angle, included bark) on the length and area of discoloration that developed after branch removal. Tukey's studentized range (HSD) contrast of means procedure was used to analyze the impact of class variables (branch collars, pith connections) on discolored area. The frequency procedure was used with chi-square analysis to test for relationships among class variables. Lastly, the difference between mean discoloration values for individual trees was determined using the Duncan's multiple comparison procedure. In all statistical analyses, $P$ values less than 0.05 were considered significant unless otherwise specified.

The models predicting discolored area from aspect ratio were used to calculate the threshold aspect ratio beyond which there was a significantly greater probability of forming severe discoloration following branch removal. The threshold level was calculated as the ratio at which the slope of the function was equal to 1 . Therefore, at the threshold ratio, an increase in $X$ (aspect ratio) resulted in a similar increase in $Y$ (normalized discolored area). Beyond the threshold ratio, a given increase in $X$ resulted in a greater increase in $Y$. To find the ratio where slope equaled 1 , the first derivative of the function was calculated and set to equal 1 . Solving for $X$ yielded the predicted threshold ratio.

\section{RESULTS AND DISCUSSION}

The area of discolored wood increased significantly ( $P$ $<0.01)$ in both species as aspect ratio approached 1. An aspect ratio of 1 indicated the presence of codominant stems (Figure 2). The normalized length of penetration of discoloration into the trunk also increased with aspect ratio for both species. These results are consistent with observations of large columns of decay that can develop following removal or breakage of codominant stems (Shigo 1985, 1986). They also support the absence of such decay in dead subordinate branches (branches with small aspect ratios) in many hardwood tree species (Toole 1961).

The predicted threshold ratios were 0.59 and 0.39 for red maple and live oak, respectively. This analysis indicated that removing a branch with lower aspect ratios than these resulted in a relatively small amount of discolored wood, whereas removing a branch that was 
more codominant resulted in a larger amount of trunk discoloration. These critical threshold aspect ratios may be useful as general indicators to predict the potential for decay development after branches are removed. Although threshold levels are likely to vary among species due to differences in wood anatomy and growth habit, the critical ratios derived here may serve as a useful starting point in forecasting the relative amount of trunk discoloration that may develop after pruning branches of the size and type utilized in this study.

There was no significant correlation between branch diameter and discolored area $\left(\log _{10}\right.$ normalized) in ei-

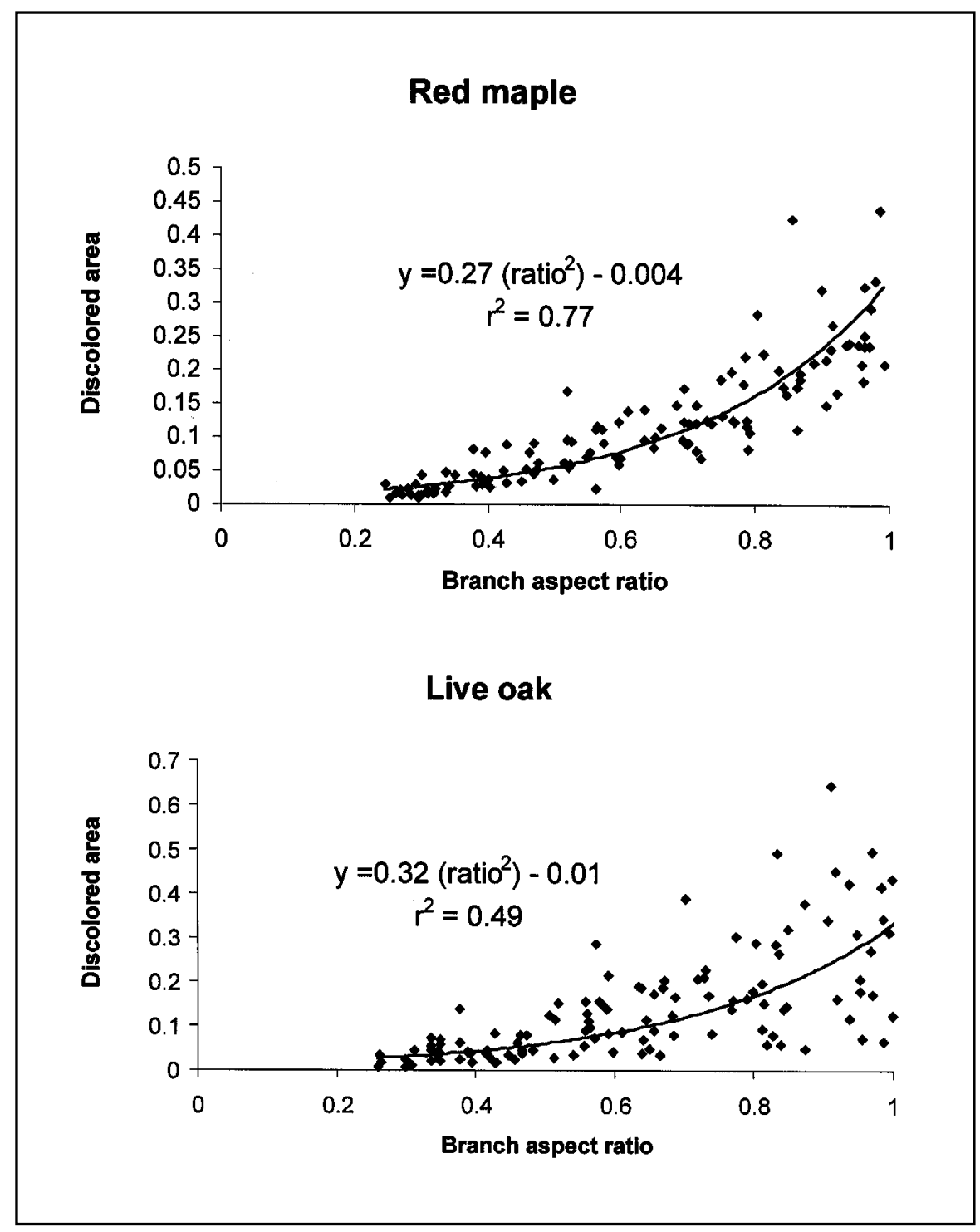

Figure 2. The impact of aspect ratio on trunk discoloration $\left[\log _{10}\right.$ discolored area $\left(\mathrm{cm}^{2}\right) \div$ trunk cross-section area $\left.\left(\mathrm{cm}^{2}\right)\right]$ that developed in the medial longitudinal plane of dissected branch junctions four months after branch removal. ther species. This finding seems to contradict past research showing that the amount of discolored wood formed interior to dead branch stubs (diameter $>1$ in.) was influenced by branch diameter (Toole 1961). However, only small-diameter branches were observed in our study. In addition, branch junctions were dissected only four months after branch removal. More extensive discoloration may have developed with time. It is likely that diameter would impact long-term discolored wood development after branch removal, particularly in large branches that contain heartwood (Shigo 1986). The results from branches in our study may be most relevant with regard to young tree (small branch) pruning; further study is necessary to test the relationship between aspect ratio and longterm trunk discoloration for branches in excess of $2.5 \mathrm{~cm} \mathrm{(1} \mathrm{in.)} \mathrm{in} \mathrm{diameter.}$

There was no correlation between the length of the cambial dieback line and any of the branch parameters measured in either species. Although some literature indicates that large amounts of cambial dieback below the pruning cut may occur when codominant branches are removed, no such relationship was observed here. However, cambial dieback may be more common when removing branches larger than those used in this study. Various methods have been proposed for locating the proper pruning cut to minimize cambial dieback and subsequent decay when removing branches that do not possess obvious branch collars (Shigo 1991; Harris et al. 1998). These methods often use the angle of branch attachment combined with the location of the branch bark ridge to determine the alignment of the final pruning cut. In this study, however, branches without visible collars were removed using cuts that extended from just outside of the branch bark ridge on the top of the branch perpendicularly through the branch, regardless of the branch angle. Because there was no correlation between length of cambial dieback and branch angle, it may be appropriate to remove small-diameter branches lack- 


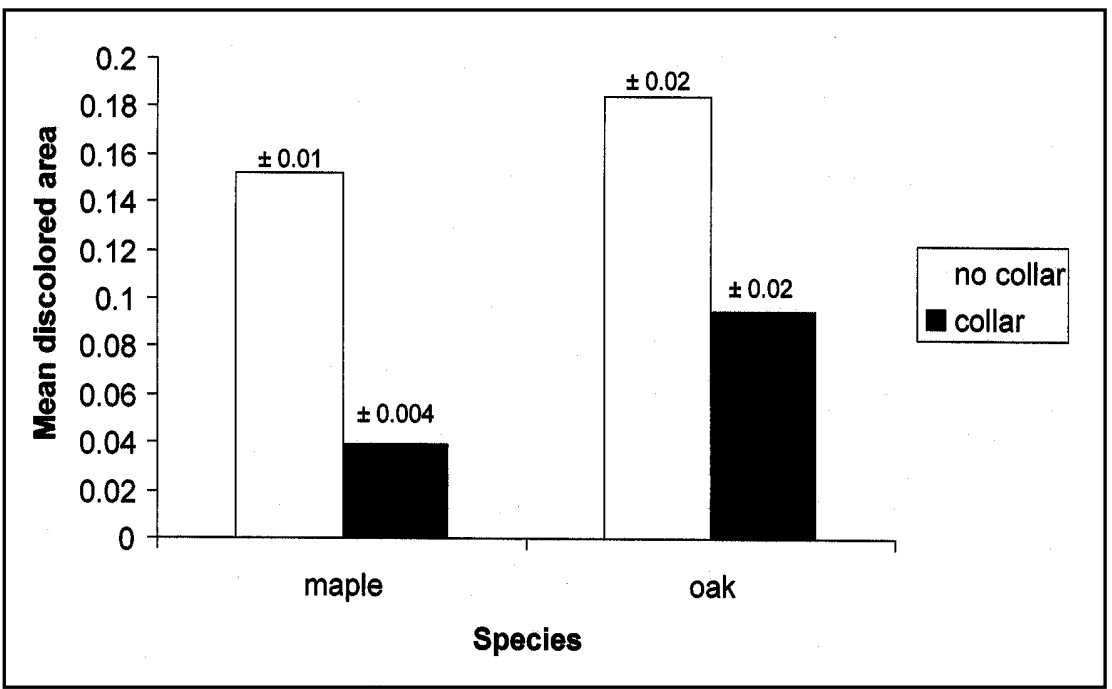

Figure 3. The effect of visible branch collars on the amount of trunk discoloration $\left[\log _{10}\right.$ discolored area $\left(\mathrm{cm}^{2}\right) \div$ trunk cross-section area $\left.\left(\mathrm{cm}^{2}\right)\right]$ that developed four months after branch removal.

ing visible collars as we did in this study (i.e., perpendicular through the branch regardless of branch angle).

Branch junctions having collars developed less discoloration after branch removal than those without this morphological feature (Figure 3). There was also a significant relationship between the presence of branch collars and aspect ratio for red maple and live oak. These results indicated that collars were most common on branches having small aspect ratios that developed relatively small amounts of trunk discoloration after branch removal. The results of our study support past observations of collars as indicators

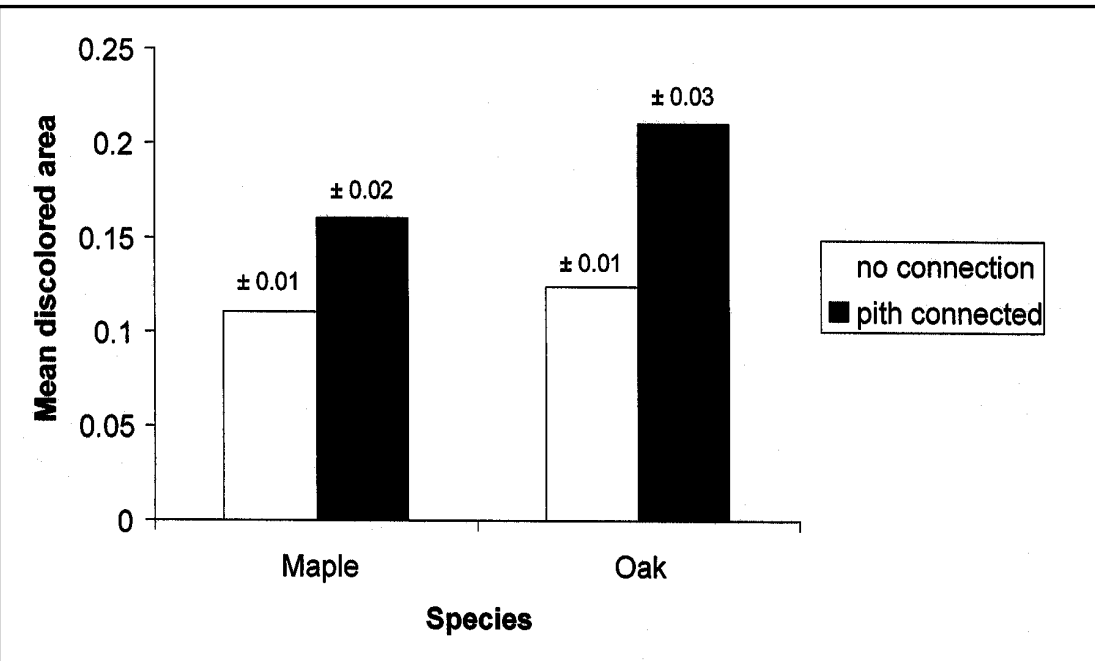

Figure 4. The impact of branch-trunk pith connections on the area of trunk discoloration $\left[\log _{10}\right.$ discolored area $\left(\mathrm{cm}^{2}\right) \div$ trunk crosssection area $\left.\left(\mathrm{cm}^{2}\right)\right]$ that developed in the medial longitudinal plane of dissected branch junctions four months after branch removal. of reduced potential for trunk decay following branch removal (Shigo 1985, 1986).

In both species, the area of discoloration was significantly greater for branches with pith connections than for those without (Figure 4). These results corroborate past observations indicating that pith connections are associated with poor compartmentalization at the branch junction (Shigo 1986). Pith connections were never observed (Table 2) in conjunction with visible branch collars in red maple and only rarely in live oak $(P<0.01)$. Branches having pith connections tended to be oriented more vertically relative to the trunk compared to branches without pith connections. Because branch-pith connections were correlated with branch collars and angle, it may be possible to use these two features to predict the presence of pith connections in a nondestructive manner. This ability could be useful to tree care practitioners in forecasting the susceptibility of branch junctions to trunk decay after branch pruning.

There was significant variation among live oak trees, but not red maple, in discolored area [values ranged from 0.059 to $0.221 \log _{10}$ discolored area $\left(\mathrm{cm}^{2}\right) \div$ trunk crosssection area $\left(\mathrm{cm}^{2}\right)$ ] that developed after branch removal. These results support past work that demonstrated the genetic control of discolored wood development after wounding in various hardwood species (Shigo et al. 1977;

Santamour 1979; Lowerts and Kellison 1981). The research protocol described in this study may be useful in tree selection programs to identify individual trees that better compartmentalize pruning wounds. Once identified, vegetative propagation may be used to selectively breed for trees with better compartmentalizing ability.

\section{CONCLUSIONS}

Based on the results of the experiments, we are able to draw the following conclusions.

- The amount of discolored wood that developed following branch removal increased with increasing aspect ratio in red maple and live oak.

- The extent of cambial dieback that resulted from branch removal was not correlated with branch angle. This 
Table 2. Frequency of branches with outwardly visible branch collars versus branches having pith continuous with trunk pith below the branch union as observed in the medial longitudinal plane of branch unions.

\begin{tabular}{llll}
\hline \multirow{2}{*}{ Collar } & \multicolumn{3}{c}{ Pith connected } \\
\cline { 2 - 3 } Red maple & No & Yes & Total \\
No & $61^{\mathbf{z}}$ & 19 & 80 \\
& $(76.3)^{\mathrm{y}}$ & $(23.7)$ & \\
Yes & 34 & 0 & 34 \\
& $(100.0)$ & $(0.0)$ & \\
Live oak & & & \\
No & 41 & 20 & 61 \\
Yes & $(67.2)$ & $(32.8)$ & \\
& 49 & 6 & 55 \\
\hline
\end{tabular}

${ }^{\mathrm{z}}$ Number of samples observed.

${ }^{\mathrm{y}}$ Row percentages.

suggests that the type of pruning cut used in this study (i.e., cutting perpendicularly through the branch) was appropriate for removing smalldiameter branches that lacked visible branch collars.

- The amount of discolored wood that developed following branch removal was significantly less in branches possessing visible branch collars than in those without collars.

- Branches with high aspect ratios or those without collars are more likely to have pith connections. Pith connections were associated with increased discolored area in both species.

- There was significant variability in discolored wood development among individual live oak trees, suggesting at least partial genetic control of wound compartmentalization in this species.

\section{LITERATURE CITED}

Aufsess, H. Von. 1975. The formation of a protective zone at the base of branches of broad-leaved and coniferous trees and its effectiveness in preventing fungi from penetrating into the heartwood of living trees. Forstwiss. Centralbl. 94:140-152.

-1984. Some examples of wood discolourations related to mechanisms for potential protection of living trees against fungal attack. IAWA Bull. 5:133-138.

Ewers, E.W., and M.H. Zimmermann. 1984. The hydraulic architecture of balsam fir. Physiol Plant. 60:453-458.

Green, D.J., W.C. Shortle, and A.L. Shigo. 1981. Compartmentalization of discolored and decayed wood in red maple branch stubs. For. Sci. 27:519-522.
Harris, R.W., N.P. Matheny, and J.R. Clark. 1998. Arboriculture: Integrated Management of Landscape Trees, Shrubs, and Vines (3rd ed.). Prentice-Hall, Englewood Cliffs, NJ. 687 pp.

Lowerts, G.A., and R.C. Kellison. 1981. Genetically controlled resistance to discoloration and decay in wounded trees of yellow-poplar. Silv. Genet. 30:98-101.

Pearce, R.B. 1991. Reaction zone relics and the dynamics of fungal spread in the xylem of woody angiosperms. Physiol. Mol. Plant Pathol. 39:41-55.

-1996. Antimicrobial defenses in the wood of living trees. New Phytol. 132:203-233.

. 2000. Decay development and its restriction in trees. J. Arboric. 26:1-10.

Pearce, R.B., and S. Woodward. 1986. Compartmentalization and reaction zone barriers at the margin of decayed sapwood in Acer saccharinum L. Physiol. Mol. Plant Pathol. 29:197-216.

Santamour, F.S. Jr. 1979. Inheritance of wound compartmentalization in soft maples. J. Arboric. 5:220-225.

Shigo, A.L. 1975. Biology of decay and wood quality, pp 1-15. In Liese, W. (Ed.). Biological Transformation of Wood by Microorganisms. Springer-Verlag, Berlin, Germany.

. 1985. How tree branches are attached to trunks. Can. J. Bot. 63:1391-1401.

-1986. A New Tree Biology. Shigo and Trees, Associates. Durham, NH. 595 pp.

- 1991. Modern Arboriculture. Shigo and Trees, Associates. Durham, NH. 422 pp.

Shigo, A.L., and H.G. Marx. 1977. Compartmentalization of decay in trees. USDA Forest Service Agricultural Information Bulletin No. 419.73 pp.

Shigo, A.L., W.C. Shortle, and P.W. Garrett. 1977. Genetic control suggested in compartmentalization of discolored wood associated with tree wounds. For. Sci. 23:179-182.

Toole, E.R. 1961. Rot entrance through dead branches of southern hardwoods. For. Sci. 7:219-226.

Tyree, M.T., and F.W. Ewers. 1991. The hydraulic architecture of trees and other woody plants. New Phytol. 119:345-360.

Zimmermann, M.H. 1978. Hydraulic architecture of some diffuse porous trees. Can. J. Bot. 56:2286-2295.

- 1983. Xylem structure and ascent of sap. In Timmel, T.E. (Ed.). Springer Series in Wood Science. Springer-Verlag, Berlin, Germany. 143 pp.

Acknowledgments. Thanks to the International Society of Arboriculture Research Trust for providing partial funding of this project. Florida Agricultural Experiment Station journal series no. R-08068. 


\author{
${ }^{1 *}$ Graduate Student \\ ${ }^{2}$ Professor \\ ${ }^{3}$ Assistant Professor \\ Environmental Horticulture Department \\ 1549 Fifield Hall \\ University of Florida \\ Gainesville, FL 32611, U.S.

\section{${ }^{\star}$ Corresponding author}

Résumé. Chez des érables rouges (Acer rubrum L.) et des chênes verts (Quercus virginiana L.) propagés par semis, le diamètre de la branche par rapport à celui du tronc (ratio des diamètres) avait une influence sur la quantité de bois décoloré qui se développe dans le tronc après que la branche soit coupée. Plus de décoloration se formait lors de l'élagage de branches codominantes que lorsque les branches étaient plus petites en diamètre que celui du tronc. Les branches avec un ratio des diamètres plus grand que 0,39 et 0,59 pour le chêne vert et l'érable rouge respectivement produisaient, après leur élagage, une sévère décoloration au niveau du tronc. La présence d'un collet était un indicateur d'un fort potentiel de compartimentation chez les deux espèces. Les branches de chêne vert et d'érable rouge qui avaient une moelle continue avec celle du tronc produisaient une décoloration plus extensive après leur élagage que celles sans lien continu entre les deux. La connexion entre les deux moelles pouvait être prédit chez ces deux espèces en se basant sur la présence d'un collet et sur l'angle d'attache de la branche avec le tronc. Il y avait plus de variabilité dans le schéma de décoloration entre les divers individus de chênes verts que parmi les érables rouges. Le dépérissement progressif du cambium, qui est souvent associé à l'élagage de branches codominantes, n'était pas affecté par aucune des caractéristiques mesurés à partir de la branche, incluant le ration des diamètres.

Zusammenfassung. Der Astdurchmesser in Vergleich zum Stamdurchmesser beeinflusste den Anteil an verfärbtem Holz, der sich nach der Entfernung von Ästen in aus Sämlingen gezogenen Rotahornen und Lebenseichen. Mehr Verfärbung resultierte aus der Entfernung von kodominanten Stämmlingen im Vergleich zu entfernten Ästen, die klein im Vergleich zum Stammdurchmesser waren. Baumteile mit einem Verhältnis größer als 0,39 und 0,59 bei Lebenseiche und Rotahorn respektive führten zu starken Verfärbungen des Stammes nach der Entfernung. Die Erscheinung von Astkragen war ein Indikator eines starken Kompartmentlisierungspotentials bei beiden Spezies. Äste mit Mark, welches Verbindung zum Stammmark hatten, entwickelten mehr ausgedehnte Diskoloration bei der Entfernung als bei den beiden Arten ohne Markverbindung. Die Markverbindung konnte bei beiden Arten durch die Anwesenheit von Astkragen und dem Winkel der Verbindung bestimmt werden Es gab eine größere Variabilität der Verfärbung zwischen individuellen Lebenseichen als bei individuellen Rotahornen. Kambiumsterben, welches öfters mit der Entfernung von kodominanten Stämmlingen gesehen wird, wurde bei keiner der gemessenen Astcharakteristika einschließlich des Größenverhältnissen beeinflusst.

Resumen. El diámetro de la rama, en relación con el diámetro del tronco, impactó la cantidad de madera decolorada que se desarrolló en el tronco después de la remoción de la rama en maple rojo (Acer rubrum L.) y encino (Quercus virginiana L.) La mayor parte de la decoloración resultó de la remoción de ramas codominantes en comparación con aquellas más pequeñas que el diámetro del tronco. Los brazos con relaciones mayores que 0.39 y 0.59 , para encino y maple, respectivamente, resultaron en decoloración severa del tronco después de la remoción. La presencia de collares de la rama fue un indicador de fuerte potencial de compartimentación en las dos especies. Las ramas con un patrón de decoloración continuo con el tronco desarrollaron una descomposición más fuerte que las que no lo presentaban. Esto puede ser predicho con la presencia de collares de la rama y ángulos de unión. Hubo más variabilidad en la decoloración entre árboles individuales de encino que en maples. La muerte del cambium, la cual está asociada con la remoción de los brazos codominantes, no fue afectada por ninguna de las características de la rama medidas incluyendo el aspecto relación rama/tronco. 